EDUR • Educação em Revista. 2021; 37:e235031

DOI: http://dx.doi.org/10.1590/0102-4698235031

() (1) https://creativecommons.org/licenses/by/4.0/

\title{
ARTIGO \\ LINHAS DE VOO DE UM BEBÊ SURDO: EMARANHADOS E AGÊNCIAS NOS PROCESSOS DE SUBJETIVAÇÃO E EDUCAÇÃO
}

\author{
HELOÍSA A. MATOS LINS ${ }^{1}$ \\ ORCID: https://orcid.org/0000-0003-4956-8185
}

\begin{abstract}
RESUMO: O artigo apresenta reflexões a partir de uma pesquisa cartográfica com um bebê surdo, colocando em questão a dimensão antropocêntrica da compreensão dos agenciamentos, onde se destaca também o papel dos fluxos materiais no processo de subjetivação dos bebês, através das contribuições do pensamento pós-humanista. Para tanto, Ingold, Deleuze, Guattari, Moss e Braidotti foram os principais interlocutores, destacando-se os emaranhados/ malhas e as intra-açoes como constructos epistemológicos nesses contextos. A partir desse giro conceitual, também são discutidas as implicações para o campo pedagógico e para os Estudos da infância. Após refletir sobre os fluxos materiais do som e outros significados nesse processo, a pesquisa contextualiza e destaca o conceito de agência antropocêntrica, contra argumentando pela consideração da força das coisas / materiais nos processos subjetivos de bebês e crianças que passam a ser compreendidos a partir de novas referências híbridas, enredadas, como seres "vazados" pelo (em direção ao) mundo. Tal dimensão analítica pode reverberar na área educacional, a partir da sensibilidade pedagógica que, para se constituir e projetar, assume a imprevisibilidade e os múltiplos/emaranhados/complexos aspectos envolvidos nas agências infantis.
\end{abstract}

Palavras-chave: bebês; subjetivação; agência; pós-humanismo; surdez

\section{LINES OF FLIGHT OF A DEAF BABY: ENTANGLEMENTS AND AGENCIES IN THE PROCESSES OF SUBJETIFICATION AND EDUCATION}

\begin{abstract}
The article presents reflections from a cartographic research with a deaf baby, questioning the anthropocentric dimension of understanding the agency and also highlights the role of material flows in the subjectification process of babies, through the contributions of posthhumanist thought. For this, Ingold, Deleuze, Guattari, Moss and Braidotti were the main interlocutors, with entanglements / meshwork and intra-actions standing out as epistemological constructs in these contexts. From this conceptual turn, the implications for the pedagogical field and for Childhood Studies are also discussed. After reflecting on the material flows of the sound and other feelings in this process, the research contextualizes and highlights the concept of anthropocentric agency, against arguing for the consideration of the force of things / materials in
\end{abstract}

\footnotetext{
${ }^{1}$ Docente dos cursos de Graduação e Pós-Graduação em Educação da Faculdade de Educação da UNICAMP. Membro do Grupo de pesquisa DIS -Grupo de Pesquisa Diferenças e Subjetividades em Educação: Estudos Surdos, das questões raciais, de gênero e da infância. Campinas, SP, Brasil. $<\underline{\text { hmlins@ } @ \text { unicamp.br }>}$ 
the subjective processes of babies and children that come to be understood from new hybrid references, entangled, as beings "leaked" by (towards) the world. Such an analytical dimension can reverberate in the educational area, based on the pedagogical sensitivity that, in order to constitute and project, assumes unpredictability and the multiple / entangled / complex aspects involved in children's agencies.

Keywords: babies; subjectification; agency; posthumanism; deafness.

\section{LÍNEAS DE VUELO DE UM BEBÉ SORDO: TRAMAS Y AGENCIAS EM LOS PROCESOS DE SUBJETIVACIÓN $Y$ EDUCACION}

RESÚMEN: El artículo presenta reflexiones de una investigación cartográfica con un bebé sordo, cuestionando la dimensión antropocéntrica de la comprensión de la agencia, donde también se destaca el papel de los flujos de materiales en el proceso de subjetivación de los bebés, a través de las contribuciones del pensamiento posthumanista. Para eso, Ingold, Deleuze, Guattari, Moss y Braidotti fueron los principales interlocutores, destacando las tramas /mallas y las intra-acciones como construcciones epistemológicas en estos contextos. A partir de este giro conceptual, también se discuten las implicaciones para el campo pedagógico y para los Estudios de la Infancia. Después de reflexionar sobre los flujos materiales de sonido y otros significados en este proceso, la investigación contextualiza y destaca el concepto de agencia antropocéntrica, contra discutiendo a favor de la consideración de la fuerza de las cosas/ materiales en los procesos subjetivos de bebés y niños que llegan a ser entendidos desde nuevas referencias híbridas, enredadas, como seres porosos abierto al mundo. Tal dimensión analítica puede repercutir en el ámbito educativo, basada en la sensibilidad pedagógica que, para constituirse y proyectarse, asume una imprevisibilidad y los aspectos múltiples/enredados/complejos que implican las agencias infantiles.

Palabras clave: bebés; subjetivación; agencia; posthumanismo; sordera

Ao Joaquim, pelo convite à viagem.

[...] o E já não é nem mesmo uma conjunção ou uma relação particular, ele arrasta todas as relações; existem tantas relações quantos $E$, o $E$ não só desequilibra todas as relações, ele desequilibra o ser, o verbo...etc. O E, 'e...e...e', é exatamente a gagueira criadora [...] Certamente, o E é a diversidade, a multiplicidade, a destruição de identidades [...] O E não é nem um nem o outro, é sempre entre os dois, é a fronteira [...] (Deleuze, 2013: 63)

\section{DELINEANDO UM ESTUDO CARTOGRÁFICO: APORTES TEÓRICO- METODOLÓGICOS E UMA CONTEXTUALIZAÇÃO DOS OBJETIVOS DA PESQUISA}

O artigo aqui apresentado refere-se à parte de uma pesquisa cartográfica com bebês (um estudo mais amplo envolvendo diversos participantes ${ }^{2}$ ), em que se manteve, como um dos

\footnotetext{
2 Projeto financiado pela Fapesp, n. 2015/ 10731-8, sob a coordenação da profa. Gabriela Guarnieri Campos Tebet, FE-UNICAMP, a quem agradeço, imensamente, por seu convite à participação no estudo e suas contribuições nesse percurso. Ver em mais detalhes no site: https://gabrielatebet.com.br/projetobebes/. Acesso em 24.01.2021.

Educação em Revista|Belo Horizonte|v.37|e235031|2021
} 
objetivos, compreender os agenciamentos construídos pelos bebês e o modo como impactam, modificam e criam novos contornos nesse processo, novas relações consigo mesmos, com crianças maiores, com os adultos e com o ambiente, buscando nos traçados-emaranhados humanos/ nãohumanos/ trans-humanos/inumanos e nos movimentos aberrantes - isto é, aqueles que se sobressaem, se distinguem - alguma pista (o que produz, segundo Braidotti, 2019, uma forma de empirismo zoo-geo-tecno-mediada ${ }^{3}$ ).

Para Rosi Braidotti (2019: 137), as cartografias têm um papel importante nessa trajetória, uma vez que são tanto o registro do que nós estamos "deixando de ser" (antropocêntricos ou humanistas, no sentido eurocêntrico, clássico e tradicional) como também "sementes do que estamos nos tornando ${ }^{4 \prime}$ (uma multiplicidade de sujeitos pós-humanos).

De acordo com esse pensamento de base deleuzo-guattariana, trata-se de buscar (num campo aparentemente homogêneo), com tais movimentos/fluxos de força e devir: "traçar um plano [...] um plano a partir do qual tudo procede e emerge [...] uma espécie de corte", um "fundo que sobe à superfície", sem deixar de ser fundo, como aponta Lapoujade (2015: 36-37). Buscar, assim, os movimentos "incomuns", "forçados", "nômades", fugazes, "um a mais de realidade"; os movimentos que atravessam a matéria, a vida, o pensamento, a natureza, por exemplo (Lapoujade, 2015; Deleuze \& Guattari, 1995; Guattari, 2012; Oliveira \& Paraíso, 2012), uma alternativa para tal compreensão/ imersão.

Cumpre destacar que, pela perspectiva deleuzo-guattariana, todo agenciamento (como rizomas e platôs ${ }^{5}$ ) é constituído por linhas - não apenas as linhas incomuns ou nômades - nos territórios/ estruturas/ superfícies. Para os autores, há as linhas fixas e duras que compõem essas estruturas e as flexíveis ou as que chamam de fora ("plano de consistência de multiplicidades" ou "linhas de fuga" (Deleuze \& Guattari, 1995: 16), de desterritorialização/ nômades/ abstratas, forças que cortam/atravessam essas superfícies (incomuns). Nesse contexto, argumentam: "Existem somente linhas" (1995: 16) e explicitam suas especificidades:

Todo rizoma compreende linhas de segmentaridade segundo as quais ele é estratificado, territorializado, organizado, significado, atribuído, etc; mas compreende também linhas de desterritorialização pelas quais ele foge sem parar. Há ruptura no rizoma cada vez que linhas segmentares explodem numa linha de fuga, mas a linha de fuga faz parte do rizoma. Estas linhas não param de se remeter uma às outras. É por isto que não se pode contar com um dualismo ou uma dicotomia, nem mesmo sob a forma rudimentar do bom e do mau. (Deleuze \& Guattari, 1995: 17)

Dado esse conjunto conceitual, os bebês são aqui compreendidos como hecceidades, virtualidades e seres constituintes de um plano de imanência ${ }^{6}$, uma vida (ou talvez até como um corpo sem

\footnotetext{
${ }^{3}$ Livre tradução.

${ }^{4}$ Idem.

5 Deleuze e Guattari assim sintetizam: "Um platô não é nada além disso: um encontro entre devires, um entrecruzamento de linhas, de fluxos, ou uma percolação — fluxos que, ao se encontrarem, modificam seu movimento e sua estrutura" (1996: 3). Assim, será do choque entre os platôs e de sua interpenetração que os movimentos de desterritorialização tornam-se possíveis (idem).

${ }^{6}$ Nessa direção, ver também Leckercq (2002), Tebet (2017) e Skliar (2014). Educação em Revista|Belo Horizonte|v.37|e235031|2021
} 
órgãos ${ }^{7}$, na acepção de Deleuze e Guattari (1996). De acordo também com Deleuze (2002), sobre os bebês:

\begin{abstract}
[...]Trata-se de uma hecceidade, que não é mais de individuação, mas de singularização: vida de pura imanência, neutra, para além do bem e do mal, uma vez que apenas o sujeito que a encarnava no meio das coisas a fazia boa ou má [...] Essência singular, uma vida... [...] os recém-nascidos são todos parecidos e não têm nenhuma individualidade; mas eles têm singularidades, um sorriso, um gesto, uma careta, acontecimentos, que não são características subjetivas. Os recém-nascidos, em meio a todos os sofrimentos e fraquezas, são atravessados por uma vida imanente que é pura potência, e até mesmo beatitude. Os indefinidos de uma vida perdem toda indeterminação na medida em que eles preenchem um plano de imanência ou, o que vem a dar estritamente no mesmo, constituem os elementos de um campo transcendental (a vida individual, ao contrário, continua inseparável das determinações empíricas). (Deleuze, 2002: 14)
\end{abstract}

Stéfan Leckercq enfatiza que, para Deleuze, essas expressões do bebê são as manifestações de uma vida que o percorre e singulariza, sem individualizá-lo: "Essa anterioridade do subjetivo deixa o bebê em um indefinido que pertence apenas ao sensível" [...] Ele é um puro acontecimento [...]" (Leckercq, 2002: 23-24).

Nessa mesma esteira analítica, faz-se importante, inicialmente, uma reflexão sobre a identificação-etiqueta sobre os bebês ${ }^{8}$, como por exemplo: surdos, cegos, míopes, ouvintes, meninos, meninas, negros, brancos, etc. Tal questão se justificaria, ainda mais, pelo fato de os bebês constituírem, em essência, vidas nômades, fluxos, aberturas, expressões, potência, imanência, o fora das territorialidades e subjetividades capitalísticas ${ }^{9}$, o fora dos dispositivos afeitos à meritocracia, capacitismo, por exemplo, inclusive aqueles de captura do território-infância ${ }^{10}$.

Diante do exposto, pretender determinar "o indeterminado", "um bebê", "uma vida", pura imanência, como bebê surdo, no caso do estudo em questão, por mais contraditório que possa parecer, é o corriqueiro, o "normal", o cotidiano, o possível nas sociedades capitalísticas: é colarlhe a identidade-etiqueta e considerar os dispositivos de poder-saber (das semióticas técnicocientíficas, principalmente, como destaca Guattari (2012: 31), controle/governo e assujeitamento (conforme as semióticas de subjetivação e de identificação/localização dos "diferentes" prevalentes em nossas sociedades), além das semióticas jurídicas e econômicas envolvidas nesse ínterim, que se amalgamam, como aponta Guattari: “O objeto do CMI [Capitalismo Mundial Integrado] é, hoje, num só bloco: produtivo-econômico-subjetivo" (2012:31).

Ao mesmo tempo, tal identidade-etiqueta tem o papel, nesse cenário, de principalmente garantir algumas existências, dar visibilidade às suas singularidades e aos seus direitos correlatos, se considerarmos o apagamento sistemático sofrido pelas minorias sociológicas, políticas e

\footnotetext{
${ }^{7}$ Argumentam os autores: "O $\mathrm{CsO}$ [corpo sem órgãos] é o campo de imanência do desejo, o plano de consistência própria do desejo (ali onde o desejo se define como processo de produção, sem referência a qualquer instância exterior, falta que viria torná-lo oco, prazer que viria preenchê-lo)" (Deleuze \& Guattari 1996: 14). Para se resgatar essa condição de "leveza" humana, então, seria preciso "substituir a anamnese pelo esquecimento, a interpretação pela experimentação" (op.cit:10).

${ }^{8}$ Não apenas a eles, evidentemente. Nessa direção, ver por exemplo as contribuições de Fernando Placer (2001).

${ }^{9}$ Guattari (2012) chama de subjetividade capitalística a resultante da semiótica "manufaturada de modo a premunir a existência contra toda intrusão de acontecimentos suscetíveis de atrapalhar e perturbar a opinião. Para esse tipo de subjetividade, toda singularidade deveria ou ser evitada, ou passar pelo crivo de aparelhos e quadros de referência especializados." (id: 34 ).

${ }^{10}$ Como argumenta Tebet (2017: 153): “O bebê é a singularidade que o dispositivo infância vai tentar aprisionar". Educação em Revista|Belo Horizonte|v.37|e235031|2021
} 
linguísticas, como também é o caso do povo surdo ${ }^{11}$, dentre outros grupos. Skliar (2014), aliás, lança uma reflexão muito sugestiva sobre esse processo de nomeação, como sendo, de fato, "de falsas acusações":

\begin{abstract}
E a interpretação da diferença resume toda a covardia dos homens, toda sua incapacidade de estar no mundo entre outros, toda essa ignorância resumida no arremessar de um nome e esconder a língua [...] Porque a diferença não é um sujeito, mas uma relação. Quando a diferença se torna sujeito, existe ali uma acusação falsa, e sem testemunho, de desvio, de anormalidade, do incompleto, castigada de discursos autorizados, renovados, sempre atuais, sempre vigilantes e tensos. (2014: 156, grifos meus).
\end{abstract}

Feita tal consideração e diante da pseudonecessidade de se identificar um bebê como surdo, vislumbrou-se com a pesquisa a possibilidade de mapear algumas relações desse bebê com a materialidade presente em sua casa/família e aquele mundo que se apresentava (de humanos, nãohumanos). Com esse intuito específico, a partir do estudo em equipe mencionado inicialmente (com escopo mais amplo), a pesquisa buscou "[...] multiplicar as formas de conexão, de linguagens, de abordagens" e, ao mesmo tempo, "Subtrair, de um conjunto dado, a unidade que o totaliza, aquilo que vem territorializando as forças que movimentam seu campo de investigação e a própria pesquisa em educação" (Oliveira e Paraíso, 2012: 163, grifos meus).

Com tal intencionalidade, foram consideradas algumas questões centrais, tais como: que espécie de unidade seria possível detectar nesse emaranhado do entre humano $E$ (i)material ${ }^{12}$ ? Que agências poderiam estar em perspectiva? Afinal, o que é/como é tornar-se/constituir-se (n)um ser (ou num surdo)? Num ser comparado, como regra, à condição da norma ouvinte? Que linhas, relevos e fluxos poderíamos observar nesses territórios formados por desejos, encontros e agenciamentos? Que movimentos/forças de repetição e ruptura (consigo, com o mundo) poderíamos vislumbrar sobre tais linhas e fluxos? Que "planos de imanência" seriam (im)possíveis ${ }^{13}$ perceber/criar como pesquisadores(as) nesse sentido? Que impactos poderíamos vislumbrar no campo pedagógico, a partir desse mapeamento?

Diante disso, um olhar mais atento procurou ser lançado - que deslocasse uma concepção antropocentrada- aos brinquedos, seres e objetos que tiveram relação com os contatos, as brincadeiras/usos de e com um bebê, os gestos e sensibilidades presentes/desencadeados e também com as representações sociais atreladas a tais artefatos (o modo como, possivelmente, os adultos e a sociedade evidenciam suas imagens e concepções sobre as crianças, os bebês e as coisas $^{14}$, nesses processos).

\footnotetext{
${ }^{11}$ Dado esse complexo contexto social e político, Boaventura S. Santos (2010) argumenta que as identidades acabam sendo semifictícias e seminecessárias.

12 O E "de Deleuze" (Deleuze, 2013), com o qual inicio este texto.

13 Aqui compreendido não apenas como o contrário do possível (o possível como o trivial, o comum, aquilo que não interrompe nada, não interrompe o "curso da história"). Conforme Derrida, o impossível, portanto, é a chance também para o possível. Para isso, é preciso, segundo ele, transformar o pensamento, ou a experiência, ou o dizer da experiência e "querer além do que se pode querer" (Derrida, 2012: 245); o que, rompendo as possibilidades, acontece.

14 Aqui, coisa não é sinônimo de objeto, na esteira do pensamento de Ingold, quando destaca: "A coisa, por sua vez, é um "acontecer", ou melhor, um lugar onde vários aconteceres se entrelaçam”. (Ingold, 2012: 29). 


\section{PÓS-HUMANISMO, EMARANHADOS E OS MODOS DE SUBJETIVAÇÃO: COMO PENSAR OS BEBÊS E AS AGÊNCIAS?}

A partir dos impactos do antropocentrismo e de seus vários efeitos devastadores sobre o planeta, surgem perspectivas que buscam - além dos saberes afeitos às epistemologias dos povos originários, como é o caso das filosofias indígena e africana, por exemplo, resgatadas pelo conceito de decolonialidade ${ }^{15}$ - forjar urgentemente novas relações entre a humanidade e a natureza, relações imbuídas de maior respeito, cuidado e sustentabilidade. Nesse ínterim, sabemos também que os modos de compreensão sobre os processos de subjetivação ${ }^{16}$ foram e são forjados pelo pensamento moderno e positivista, em que a cultura é concebida como separada da natureza. Historicamente, fruto desse fenômeno do pensamento antropocentrado, como Guattari (2012) alertava, tem sido a manifestação de um "sentimento coletivo de pseudoeternidade" (p. 34), onde a subjetividade capitalística "se inebria, se anestesia a si mesma" (2012: 34).

Temos, portanto, como chave analítica desse modelo, o controle absoluto e racional do homem, de tudo o que ela examina, exercendo escolha e domínio irrestritos sobre tudo o que não é humano, seja animado ou não, além de negar sistematicamente a possibilidade de agência a todos esses não-humanos (Moss, 2019). Humanos e não humanos ficam cindidos, binariamente, como apontado. Tim Ingold, neste sentido, aponta o que tem sistematicamente ocorrido: "divisão metafísica entre sujeitos e objetos (atribuindo a estes uma agência fetichizada)" (2012: 25).

Ingold também salienta que a atual ênfase da literatura na agência material é consequência de uma simplificação das coisas como objetos e de sua "retirada" dos processos vitais (da ênfase na vida). Segundo Ingold, os pesquisadores, ao invés de compreenderem a materialidade como tal, deixam de vislumbrá-la como fluxos de materiais.

Será justamente na contramão desse pensamento dualista apontado que surge a compreensão pós-humanista (ou sua re-articulação, se considerarmos os saberes originários), como uma "ferramenta de navegação" (Braidotti, 2013, citado por Moss, 2019: 142) acerca da interconexão de pessoas, coisas e ideias.

Moss (2019) ressalta o caráter fundamentalmente transdisciplinar da área, onde se concebem diversas perspectivas e metodologias, incluindo campos relativamente novos, como estudos de ciência e tecnologia, estudos com animais, filosofia pós-humana/ ética e humanidades ambientais, a partir das contribuições de Foucault, Deleuze, Guattari e de estudiosos como Braidotti (2019; 2013), Lenz Taguchi (2010), Haraway (2004), Taylor (2013) e Murris (2016), por exemplo.

Do mesmo modo, Ingold (2012), ao propor a retomada da noção de "coisa", porosa e fluida, atravessada por fluxos vitais e integrada aos ciclos e dinâmicas da vida e natureza, defende: “[...] não é apenas a mente que vaza, mas as coisas de modo geral” (Ingold, 2012: 42).

\footnotetext{
${ }^{15}$ Embora possamos articular uma série de aproximações com tal perspectiva, em função dos objetivos mais estritos deste trabalho, tal discussão será brevemente apontada. Ver mais a respeito do pensamento decolonial/descolonial, por exemplo, em Acosta (2016) Mignolo (2017), Quijano (2005), Walsh (2009) e Oliveira e Candau (2010), onde as epistemologias do sul (Santos, 2010) são essenciais nesse modo de compreensão, isto é, são fundamentalmente não eurocêntricas. Não estamos tratando, portanto, de pensamentos necessariamente sinônimos, mas relacionados.

16 Refiro-me aqui à compreensão da subjetividade como a capacidade "pessoal-sensorial-sentimental-cognitiva. Por meio dela se produz a experiência da subjetividade enquanto 'sujeito', intrínseca à nossa condição sociocultural e moldada por seu imaginário” (Rolnik, 2018: 52). Um modo de apreensão do mundo (afetos e perceptos).
} 
Nessa direção, cumpre articularmos, mesmo que brevemente, muitos dos aspectos das referidas epistemologias ancestrais/afro-indígenas - dentre outros saberes fortemente combatidos pelo pensamento eurocêntrico (um dos principais responsáveis pela situação atual do binarismo homem/cultura x natureza, evidentemente) - que, desde que se tem notícia, manifestam essa compreensão de mundo, buscando preservar em suas culturas outros modos de subjetivação e vida, diante da violência (não apenas simbólica) da histórica e cotidiana colonialidade (e muito antes dela!). Aliás, em obras recentes, Boaventura Sousa Santos (2019; Santos \& Martins, 2019) menciona a importância da recuperação das ferramentas analíticas desses povos ancestrais para novas lutas pela dignidade no planeta, de pensamento e ação, dentre outros aspectos: o que chama de epistemologias pós-abissais.

Braidotti (2019) também celebra esse modo de compreensão do mundo: "interrelacional, transnacional, multi-sexos e trans-espécies [...]" como "uma forma nativa ou vernacular de cosmopolitismo" (Braidotti, 2019: 127)

Sobre tal dimensão, Moss faz uma importante nota ao fato de que o humanismo também tem sido associado a uma agenda emancipatória que inclui solidariedade, justiça social e igualdade, mas o pós-humanismo não rejeita essa agenda para melhoria humana. Assim, destaca que o pós-humanismo objeta a 'violência epistêmica' (Braidotti, 2013: 30, citado por Moss, 2019: 147), exercida pelo humanismo eurocêntrico a todos os ocupantes do planeta.

Diante desse breve contexto, podemos situar uma concepção outra sobre os processos de ensino-aprendizagem e subjetivação/ singularização ${ }^{17}$, através da ideia dos emaranhados ${ }^{18}$. Significa atentar para, mais especificamente, o aprendizado que não segue um caminho linear, com estágios progressivos e/ou previsíveis. Como aponta Moss (2019), pelo contrário, procede por encaixes, partidas e desvios inesperados, envolvendo linhas de $v o 0^{19}$, que se iniciam de maneiras imprevisíveis, provocadas por forças do devir e por encontros com diferenças, à medida que novas conexões são feitas e novas hipóteses são colocadas à prova diante de outras. A metáfora de Malaguzzi, de Reggio Emilia ${ }^{20}$, como retoma Moss, é a de um emaranhado de espaguete, "sem começo nem fim, mas onde você está sempre no meio e com aberturas para muitos outras direções e lugares" (Moss, 2019: 71. Livre tradução; Dahlberg e Moss, 2020).

Neste sentido, cumpre mencionar que Ingold (2012; 2015) nomeia também tais linhas como linhas de voo (que não são fixas ou duras como elementos de um território), na acepção

\footnotetext{
17 Considerando o referencial apontado com Guattari (2012), por exemplo, vinculado às suas bases deleuzianas também.

18 Gunilla Dahlberg e Peter Moss aproximam essa ideia do conceito de rizoma em Deleuze e de linhas de voo (Rinaldi, 2006: 7, citado por Moss, ibid., p. 123; Dahlberg \& Moss, 2020; Rinaldi, 2020). Moss e Dahlberg enfatizam que a autora também relaciona o pensamento à experimentação e problematização e as linhas de voo são um conceito, por ela usado, para indicar um processo do "vir a ser" (porvir), como substrato de uma verdadeira educação (Dahlberg \&Moss, 2020). A ideia de movimentos aberrantes de Deleuze, neste sentido, parece-me muito próxima também.

19 Nas obras brasileiras, nesse contexto, valeria explorar mais os usos do termo para os estudos de bebês, principalmente: pela ideia do imprevisto no desenvolvimento/encontros/agenciamentos, enfim, na criação híbrida/emaranhada/amalgamada, de fato, nesse trajeto, de modo que não se percebam as possíveis "pontas" como existentes/localizáveis e compreendidas "em si". Neste sentido, seria importante não considerar as pontas, mas as aberturas "sem começo nem fim" (Dahlberg \&Moss, 2020: 30).

${ }^{20}$ Refiro-me ao projeto educativo da cidade de Reggio Emilia, no nordeste da Itália, de que Loris Malaguzzi foi inspirador/mentor. A esse respeito, ver por exemplo Rinaldi (2020) e Bujes (2008). Neste trabalho, aliás, através de análise pós-estruturalista do discurso, a autora tece críticas aos sentidos do regime de enunciação empregado pela escola e às possibilidades de governamentalidade das crianças pelas políticas públicas, apesar dos avanços e da vontade de "fazer diferente".
} 
deleuzo-guattariana e, ocasionalmente, as assume também como linhas de devir, de modo que tal conceito parece explicitar mais a ideia de uma "viagem-criação".

Assim, opto aqui pelo termo linhas de voo no lugar de linhas de fuga, como também encontramos em tradução da obra deleuzo-guattariana, mais frequentemente. Não se trata também, deste ponto de vista, de sinônimos. Aliás, vale ressaltar a provocação de Moss (2019) para que coloquemos uma movimentação destacada sobre as linhas fixas e linhas duras, para que possamos criar nomes/ideias/conceitos para além dos dados por Deleuze e Guattari. Enfim, a ideia do "espaguete" trazida por Moss, surge nessa empreitada, assim como em Dahlberg e Moss (Dahlberg \&Moss, 2020; Rinaldi, 2020).

Neste caso, então, valeria a pena o uso de da ideia de voo ou devir, para nos referirmos, mais detidamente, aos processos que atravessam, arrastam e hibridizam tais linhas e os territórios que compõem. Aqui enfatizo, particularmente, o caso dos bebês/hecceidades nesses percursos. Ingold (2012) ressalta que

a vida, para Deleuze e Guattari, se desenrola ao longo dessas linhas-fio; eles a chamam de 'linha de fuga', e por vezes 'linhas de devir'. O mais importante, contudo, é que essas linhas não conectam. [...] os pontos não são conectados, mas colocados de lado e tornados indiscerníveis pela corrente à medida que ela se arrasta através deles. A vida está sempre em aberto: seu impulso não é alcançar um fim, mas continuar seguindo em frente. (Ingold, 2012: 38-39).

Retomando essa concepção de devir como meio (e não como uma ideia de pontos ou entre pontos), Ingold - na obra intitulada "Estar Vivo, ensaios sobre movimento, conhecimento e descrição" - retoma a ênfase dada por Deleuze Guattari: "Um ponto é sempre um ponto de origem. Mas uma linha de devir não tem começo nem fim [...] [Ela] tem apenas um meio [...] Um devir está sempre no meio: só se pode obter pelo meio. Um devir não é um nem dois, nem a relação dos dois; é o intermediário [...] (Deleuze \& Guattari, 2004: 224-225, como citado por Ingold, 2015: 137)

Como observaremos, a seguir, no caso dos agenciamentos com Joaquim, o bebê em questão, fica latente esse aspecto das linhas de devir/voo como criação ("vir a ser"), a partir também da (i)materialidade do som e da luz nesse percurso, num plano de imanência singular, em que o cotidiano ou intuitivo causam espanto nele (bebê surdo) e em quem se deixar levar pela experiência do encontro. Importante também destacar que tal espanto/(re)encantamento/ criação (como valorização-experimentação de cada momento vivido) se dá a ver/sentir/perceber talvez ainda mais em contextos da diferença sensorial-visual humana, por exemplo (ouvir-ver-sentir). Ingold (2015) nos ajuda também a considerar, nessa direção: "o tipo de espanto que advém da valorização de cada momento, como se, naquele momento, estivéssemos encontrando o mundo pela primeira vez, sentido seu pulso, maravilhando-nos com a sua beleza e nos perguntando como um mundo assim é possível” (Ingold, 2015: 112). É como se a vida fosse esse levante possível (um flanar?), através da força/pulso provocado pelos voos/ devires das experiências iniciais.

Considerando tais aspectos, Ingold (2015) defende que se crie uma "fenomenologia da experiência", conforme Deleuze e Guattari, e não apenas uma "ecologia do real", ou seja, o autor não concebe, como regra, que seja factível identificar ou definir contornos (neles mesmos), a partir dos encontros e agenciamentos que compõem os emaranhados/ rizomas. Somente numa conjunção é que novas e inesperadas nuances do ser-sentir-pensar se darão. Sintetiza Ingold que "Os 
sistemas vivos são caracterizados por um acoplamento de percepção e ação [...] Este acoplamento é tanto uma condição para o exercício da agência quanto da fundação da habilidade" (Ingold, 2105: 113, grifo meu)

Moss (2019) também compreende, nesse bojo, o conhecimento como a criação de algo novo, apoiado em outros estudiosos da área, alguns dos quais aqui já citados; conhecimento como criação de novas propriedades "que nunca existiram antes e, mais importante, são inconcebíveis do que veio antes" (Osberg \& Biesta, 2007, p. 33, citado por Moss, 2019: 71). Será justamente por isso que as ideias sobre imprevisibilidade, espanto e admiração tornam-se valores importantes na educação infantil de Reggio Emilia e de sua pedagogia das relações e escuta ${ }^{21}$.

Resumidamente, como aponta Moss (2019), tanto Deleuze como Reggio Emilia concebem que o aprendizado não pode ser reduzido a algo que pode ser previsto, à reprodução de padrões predefinidos por meio da "pedagogia profética". Pelo contrário, trata-se "de estar aberto e acolher o surgimento do ainda não-pensamento, em si e nos outros. Como tal, quando isso acontecer, será surpreendente, imprevisível e uma causa de admiração" (Moss, 2019: 123. Livre tradução. Grifos meus).

Feitas tais considerações sobre a importância de uma compreensão afeita aos emaranhados (ou malhas/ meshwork, como também nomeia Ingold, a partir de Lefebvre, Ingold, 2012; 201522 e de uma alternativa ao antropocentrismo, buscou-se pela concepção de agência expandida, uma vez que, nessa perspectiva, os seres e coisas tornam-se "agentes performativos", no mesmo grau de importância (em termos de afecçôes), digamos assim.

Neste sentido, temos que imaginar um mundo em que os sujeitos - humanos ou não humanos, animados ou inanimados - "são" porque estão em relação e influenciando um ao outro, todos enredados e passa a ser impossível dizer onde estão os limites (por exemplo, de cada criança/ das crianças, professor/ adulto(s) e as coisas). Em tais relações de reciprocidade, toda a matéria altera e muda as intra-ações em andamento, como nos lembra Moss (2019).

Para a compreensão dessa concepção de agência, o autor faz também referência a Karen Barad (2009, citado por Moss, 2019), apontando que é preciso deslocar a própria noção de indivíduos que existem independentemente. Ao contrário, a agência passa a ser compreendida como uma encenação, uma questão de possibilidades para reconfigurar emaranhados. Segundo Barad, agência não tem a ver com escolha, em nenhum sentido humanista liberal, mas "sobre capacidade de resposta, sobre as possibilidades de resposta mútua" (Barad, 2009, citado por Moss, 2019: 145). Nessa direção, portanto, que se dá a ideia de arrastamento e hibridização de pontos nas redes tecidas (indiscerníveis, como dito por Ingold, 2012), como mencionado.

\footnotetext{
${ }^{21}$ Como também aponta Moss (idem), uma pedagogia das relações tem como centralidade a interação e o diálogo entre crianças e adultos na construção do conhecimento (por conseguinte, a importância da ética relacional), mas também a importância das relações entre as línguas. Nessa direção, a pedagogia da escuta reconhece a "importância de escutar o pensamento - as ideias e teorias, perguntas e respostas de crianças e adultos. Significa tratar o pensamento com seriedade e respeito; significa lutar para dar sentido ao que é dito, sem ideias preconcebidas do que é correto ou apropriado" (Rinaldi, 2006: 15, citado por Moss, ibid.: 71. Livre tradução). A esse respeito, ver Rinaldi (2020).

${ }^{22}$ Ingold (2015) diz que tais malhas são constituídas por linhas "de interação" e "não de fuga" (p. 111). Segundo ele, por trás da imagem convencional de uma rede de entidades que interagem - aquilo que chama de malha - estão linhas emaranhadas "de vida, crescimento e movimento" e não se trata de pontos conectados, "mas uma malha de linhas entrelaçadas" (idem, p. 111). Nesse aspecto, aliás, além das aproximações, aponta afastamentos diante da concepção de Bruno Latour, principalmente na compreensão de rede como conexão de pontos (cita, inclusive questões tradutórias da obra de Latour, neste sentido). Para Ingold, trata-se de um entrelaçamento de linhas.
} 
Portanto, a recente revisão teórica sobre o conceito de agência infantil, realizada por Pavez Soto e Sepúlveda Kattan (2019), mostrou-se muito relevante para contextualizar o campo e sugerir um terreno epistemológico para que se concentrassem as principais reflexões do presente estudo. As referidas autoras destacam que o conceito de agência ainda está em fase de consolidação em nível teórico das ciências sociais e dos estudos da infância, embora não haja um destaque aos bebês nesse levantamento realizado pelas autoras. Ainda assim, enfatizam a utilidade e pertinência do conceito para se definir e compreender a ação social que desenvolvem as crianças no mundo atual.

Conforme apontam, a partir do enfoque nas publicações de origem hispânica e latinoamericana, os estudos da infância têm argumentado que as crianças conhecem, compreendem e explicam o mundo em que habitam e as relações sociais em que estão imersas, tendo um ponto de vista sobre isso. Assim, tais estudos vêm afirmando a agência infantil como uma competência constitutiva da criança (a "positividade" da infância). De modo geral, significa compreender que os estudos da infância têm questionado sobre quais espaços sociais são possíveis para a agência infantil, onde se evidenciam essas agências, como e onde as crianças exercem seu poder (tal como concebido por esse campo), o que inibe ou promove o exercício dessa dita agência, entre outros aspectos, tendo como destaque as pesquisas de Anthony Giddens, Pierre Bourdieu e Amartya Sen, assim como Berry Mayall y Leena Alanen (Pavez Soto \& Sepúlveda Katan, 2019).

Como sintetizam as autoras, ainda que a importância desse aspecto seja inegável, a agência infantil está ainda invisibilizada socialmente. Diante disso, sustentam a urgência no favorecimento de participação social das crianças que deveria se basear não só em atitudes de abertura, mas em mecanismos, metodologias e políticas em nível institucional, para que seja possível sua efetivação.

Nesse contexto, considerando a invisibilização mais ampla da agência das crianças, como mencionado, depreende-se que a dimensão da agência dos bebês e a compreensão de suas relações com o mundo (sujeitos e coisas) são ainda bastante lacunares como campos epistemológicos nas ciências sociais e nos estudos da infância. Afunilando ainda mais esse espectro, por certo, podemos considerar a escassez de estudos numa perspectiva sobre os bebês surdos e seus processos de subjetivação, bem como de processos pedagógicos nessas trilhas.

A partir dessa observação, para tal estudo, foi importante traçar um breve levantamento bibliográfico a respeito e, diante dele, pode-se ainda afirmar que os estudos com bebês surdos, numa perspectiva não filiada ao ideário clínico-terapêutica (Skliar, 1997) e positiva/ potencial da infância (Sarmento, 2005) - ou mesmo sobre as agências e emaranhados - são ainda um campo quase inexplorado.

\section{Breve traçado sobre as pesquisas atuais com bebês surdos}

A título de exemplo, numa busca realizada em janeiro de 2020 no site da Biblioteca Digital Brasileira de Teses e Dissertações (IBCT: http://bdtd.ibict.br/), com os marcadores "bebê" e "surdo", 05 pesquisas (realizadas entre 2009 e 2017) foram encontradas. A partir da leitura dos títulos e resumos de 35 ocorrências (busca alternativa da plataforma pela palavra "surdos"), apenas os 05 trabalhos estavam relacionados mais diretamente aos temas acima apontados e apresentaram 
os seguintes focos: implante coclear de bebês surdos, bebês surdos na Educação Infantil, relação mãe ouvinte e bebê surda, fala materna e bebê surdo implantado.

No portal do Scielo (www.scielo.com), com os mesmos marcadores não houve nenhuma ocorrência, nessa data de busca. Quanto ao Portal da Biblioteca Virtual em Saúde (https://pesquisa.bvsalud.org/), no mesmo período e com os mesmos marcadores (com ou sem acréscimo do campo local de produção: "Brasill"), não houve ocorrência registrada. Com os marcadores "deaf" e "baby" (com o filtro "deafness"), 44 ocorrências foram encontradas nas bases Medline (43) e Lilacs (01), tendo como principais temas: genética, práticas neonatais, implante coclear, fonoterapia, triagem, diagnóstico, linguagem, educação precoce, perinatologia, inseminação artificial, desenvolvimento da personalidade, audiometria, entre outros.

Diante desse cenário, aliás, cumpre ressaltar as fronteiras epistemológicas presentes em nossas universidades e agências de fomento, não raramente encontradas, que acabam por reforçar uma separação entre "essas e outras" crianças e "esses e outros" bebês (a pseudonecessidade de identificação, como inicialmente aqui argumentado). Certamente, há vários outros exemplos dessas dicotomias também fetichizadas, desde a Modernidade, que dificultam uma compreensão mais plural/híbrida e que geram as referidas invisibilidades ou apagamentos existenciais, consequentemente analíticos para a área, dentre outros aspectos. Sem dúvida, tais aspectos dificultam substancialmente a compreensão sobre os bebês (todos) como essências singulares (hecceidades), nas malhas/emaranhados com as coisas (não apenas os objetos, mas os fluxos do devir, o local do entrelaçamento dos aconteceres no/com o mundo que também re-age, como será analisado na sequência).

\section{Pensando os fluxos materiais e as agências/imanências com um bebê surdo}

Como até aqui argumentado, os sujeitos não estão sozinhos como "agentes" ou em "desempenhar/ter/possuir agência". Na perspectiva assumida, não há, portanto, uma divisão entre os seres humanos como ativos e intencionais - os poderes que exercem ação - com todo o resto que forneceria um pano de fundo passivo a ser explorado ou usado. Em vez disso, tudo é dinâmico, (inter-intra-) agente, como nos lembra Moss (2019).

Moss (2019) ainda destaca que a ideia espinosana de que "nunca sabemos com antecedência o que um corpo pode fazer" aplica-se tanto aos corpos humanos como aos nãohumanos. O autor, retomando a teoria de Barad sobre o "realismo agencial", destaca também esse entendimento estendido da agência que não se refere a um processo simples e interativo, de um agir do outro, uma relação direta de causa e efeito, mas através de "um processo dinâmico de ação interna". Como enfatiza: "Esta é uma teoria epistemológica e ontológica; isto é, reconceitualiza como o conhecimento é criado e também como a realidade é realmente moldada" (Moss, 2019: 144).

O autor destaca a importância de se conceber uma ação interna acontecendo nas relações; refere-se a algo acontecendo "entre diferentes corpos". O conceito de "intermediário" é importante para repensar a agência, segundo Moss (2019), passando de uma ideia simples de "A" atuando em "B" para uma ideia mais complexa de emaranhados, em que emerge algo novo do que chama de inter-ação. 
Trazendo o pós-humanismo para o campo pedagógico e para a reflexão sobre os bebês, faz-se relevante explorar as implicações [para a educação] do envolvimento do humano e do não-humano, assim como do envolvimento discursivo e do material. Essa pedagogia intra-ativa, segundo Moss, começa com uma série de perguntas importantes:

É possível pensar de outra maneira que não separe a matéria como "morta" ou passiva em relação à discursiva? É possível pensar no material das práticas da primeira infância como tendo uma agência própria? Podemos pensar no material como sendo ativo na produção de nossa criação de significado da criança e do aprendizado e de nós mesmos como professores? Seria possível pensar no material como ativo na produção de nossa criação discursiva de significado? (Taguchi, 2009: 29, citado por Moss, 2019: 150)

Assim, todos os tipos de organismos e matérias são entendidos como agentes performativos, como mencionam os autores com os quais aqui se dialoga. Significa conceber que essa pedagogia intra-ativa - uma pedagogia influenciada pelo pós-humanismo - impõe o reconhecimento e o trabalho com seres materiais "tão ágeis quanto os seres humanos e com a natureza interdependente e emaranhada da relação entre coisas, matéria e organismos, sempre nas relações de ação" (Moss, 2019: 150). Como tal, eles não apenas dependem um do outro, mas também se afetam mutuamente o tempo todo. Como argumentado, os materiais importam, reagem e podem alterar a criação dos emaranhados, portanto.

Como decorrência dessa compreensão, a criança (também agente) não é o centro das coisas, mas parte de uma rede ou de relações emaranhadas que conectam o humano e o nãohumano, o trans-humano, a cultura e a natureza, o material e o discursivo. As relações são essenciais para tudo e não as crianças em si mesmas, como também apontam os autores. Diante disso, o mesmo é aqui concebido sobre a importância dos bebês nesses processos inter-ativos e como também apontado a seguir, no caso de Joaquim.

\section{Joaquim $E$ os fluxos "que vazam"}

Segundo Lenz Taguchi: "O material afeta nossos entendimentos discursivos tanto quanto nossos entendimentos discursivos afetam a realidade material ao nosso redor" (Taguchi, 2010: 30, citado por Moss, 2019: 150). Com base nessa reflexão, o encontro de nossa equipe com Joaquim $^{23}$ e sua mãe (com cerca de uma hora de duração, em sua casa, em junho de 2019) fez-me atentar para a proeminência [também] das coisas como agentes das/nas relações.

Naquela tarde, enquanto fui apresentada ao Joaquim (muito sorridente) - então com 7 meses e usuário de aparelho auditivo, ocasionalmente ${ }^{24}$ - abri meus braços, enquanto nos

\footnotetext{
${ }^{23}$ Nome fictício.

${ }^{24}$ Joaquim (bebê do sexo masculino, branco) foi-me apresentado como surdo profundo bilateral. Após contato da coordenadora responsável pela pesquisa (que apresentou os principais objetivos do estudo, os termos do TCLE Termo de Compromisso Livre e Esclarecido - e dinâmica dos encontros com duas pesquisadoras da equipe), os pais (ambos ouvintes) aprovaram a proposta e a mãe acompanhava as sessões - que duravam em torno de 01 hora mostrando-se bastante receptiva com a equipe. Mantínhamos um diálogo rotineiro e buscávamos também discutir algumas questões afeitas à surdez, às possíveis contribuições da Libras - Língua Brasileira de Sinais - à vida de outros surdos, em distintos períodos (com ou sem implante coclear). Dialogávamos sobre as impressões da mãe nesse contexto, dentre outros assuntos, enquanto se observava Joaquim e suas relações, numa rotina que não foi alterada de 
olhávamos com muita atenção, acreditando que pudesse se interessar pelo meu colo. De fato, jogou seu corpo em minha direção e a mãe o ajudou nessa empreitada. Já comigo, imediatamente, segurou um colar que eu usava na ocasião (Imagem 1) e, assim, entramos na casa.

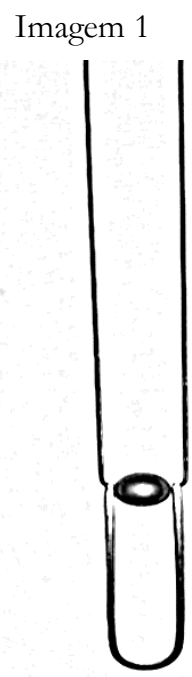

Fonte: acervo da autora

A partir desse momento, já na sala (com vários objetos presentes e disponíveis, inclusive o que culturalmente representamos como brinquedos para crianças), quase toda a dinâmica e os fluxos daquele encontro foram emaranhados pelo colar. Isso significa conceber uma agência expandida, em que as inter-ações adultos-bebê, as narrativas dos adultos, o que se tornou (e o que não se tornou) brincadeira para o bebê (que permaneceu sentado no meu colo, no tapete da sala, brincando com o colar, a maior parte do tempo), nossas (sens)ações de reciprocidade, as projeções da equipe sobre o próximo encontro ${ }^{25}$, a escolha por parte de uma das pesquisadoras em registrar os contornos daqueles acontecimentos, enfim, foram agenciadas pelas linhas de força com o colar (que chamaram a atenção de Joaquim, bem como o destaque a um relógio de pulso também meu - Imagem 2 - que passa a ser de seu interesse, já mais ao final do encontro).

Interessante ressaltar, nesse contexto, como Joaquim buscava o contato com alguns objetos e pessoas. Dentre as opções que se apresentaram, de fácil alcance, apenas algumas acabam sendo seu alvo (E apenas algumas se lançam a olhar/explorar).

modo significativo por nossa presença. Nesse período, o bebê não frequentava a creche; recebia um atendimento especializado semanal, na área médica (pediátrica) e também fonoaudiológica (Faculdade de Ciências Médicas - FCM - e CEPRE, Centro de Reabilitação Gabriel Porto, ambos na UNICAMP) e já usava um aparelho de amplificação sonora móvel, usado externamente (tipo BTE - retroauricular). Ao final desse período de visitas, a mãe informou que Joaquim faria a cirurgia para o implante coclear, prevista para o fim do ano de 2019.

25 De modo geral, foram observados e registrados (em vídeo, fotografias e caderno de campo) os brinquedos disponíveis a Joaquim, suas brincadeiras, ações/ interações/ agenciamentos nesse contexto. Na maior parte das sessões, além da minha presença, havia mais uma pesquisadora (numa ocasião a coordenadora do projeto e, em outras, uma estudante do PPGE -UNICAMP, vinculada à pesquisa). 


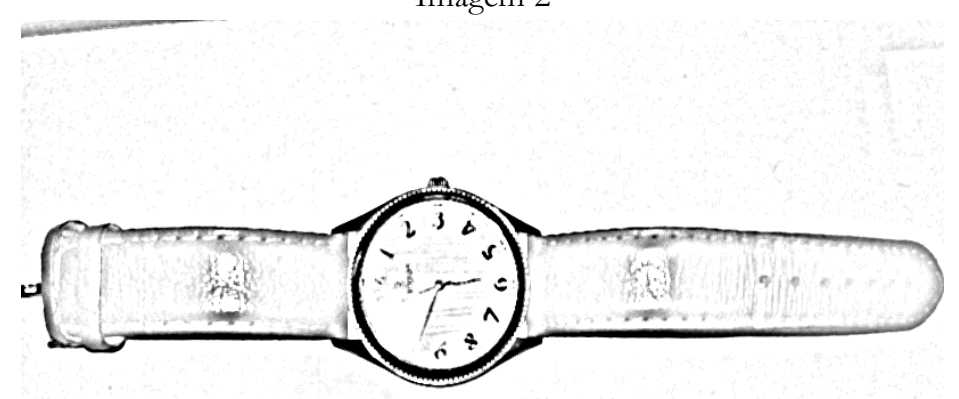

Fonte: acervo da autora

Uma reflexão surgida, a partir dessa visita, refere-se justamente aos objetos que se tornam coisas (pela energia, pela vida despertada), como Ingold nos ajuda a compreender: a coisas que geram os acontecimentos, como já mencionado; as coisas como "um lugar onde vários aconteceres se entrelaçam" (Ingold, 2012: 29) e também se tornam coisas para brincar, na perspectiva do bebê e dos adultos.

Significa atentar, por exemplo, à acepção de Brougère (2010: 20), quando argumenta que a infância é um momento de apropriação de imagens e de variadas representações que circulam por diferentes canais e fontes. O brinquedo, desta maneira, é uma dessas fontes para o autor que destaca sobre tal artefato cultural: "Se ele [o brinquedo] traz para a criança um suporte de ação, de manipulação, de conduta lúdica, traz-lhe, também, formas e imagens, símbolos para serem manipulados" (2010: 42). Tais concepções estão diretamente vinculadas ao que o Brougère considera como cultura lúdica (Brougère, 2010), isto é, diferentes suportes concebidos como dispositivos materiais também que têm se configurado como brinquedos para as crianças e os bebês na contemporaneidade (o brinquedo como mídia, nas palavras de Brougère).

Brougère ainda destaca, no que se refere à "cultura da criança", que esta se constitui, entre outros aspectos, como um ambiente composto de objetos e, particularmente, de brinquedos (parque de brinquedos, como um conjunto organizado, Reme, 1984, citado por Brougère, 2010). Assim, o brinquedo contribui para o desenvolvimento dessa chamada cultura lúdica. Em síntese, tais artefatos são compreendidos como fortes conteúdos simbólicos do universo adulto, por representarem uma concepção de criança (ou mais), "na medida em que se trata de um objeto escolhido por adultos e destinado a uma criança pequena" (Brougère, 2010: 69). De qualquer modo, o autor considera ainda que as crianças e bebês também podem (re) criar modos ainda desconhecidos, a partir de seus movimentos de individuação e subjetivação.

Para além dessa concepção (que particularmente se aproxima deste estudo), imbuídos da percepção pós-humanista, é possível argumentar que esses modos ainda desconhecidos são também provocados pelas coisas/fluxos que se insinuam/ provocam e movimentam os bebês. Além disso, é possível conceber os brinquedos como coisas "com vida", que geram fluxos (inesperados), como vimos, e não meros objetos/ artefatos destinados à infância, seja pela indústria ou, de modo geral, como um material cultural com determinada finalidade (assim representado).

O que podemos lançar em perspectiva, a partir dessa cartografia sobre as forças do encontro com/de Joaquim (e não apenas no mapeamento de pontos-objetos desse território, assim como alguns traçados e relações entre os mesmos), por exemplo, é que as crianças e, 
principalmente, os bebês, por tudo que já foi aqui apresentado, percebem o devir-brinquedo, detectam "a vida" e a força das coisas, da natureza, dos seres, em dimensões inter-intra-subjetivas que talvez não percebamos mais como adultos (particularmente, nós, os membros deste tipo de sociedade capitalista e antropocêntrica que cindiu a relação humanidade-mundo). Vale também destacar que os pontos de um tipo de exercício/ registro cartográfico são, portanto, arrastados e amalgamados em novos elementos (e modos de compreensão desses elementos) que se dão a cartografar (e que podem mudar as maneiras de se mapear esses agenciamentos, como aqui procuro evidenciar, através de uma narrativa com imagens).

Será neste sentido também que, com Ingold (2012; 2015), por exemplo, podemos pensar não em termos de brinquedos como meros objetos (como apenas pontos no território "sala", por exemplo, no caso aqui referido), mas de quaisquer elementos porosos e fluidos que agenciam os bebês e as crianças ${ }^{26}$ (hibridizando-os/ transformando-os mutuamente).

Podemos conceber, portanto, essas coisas atravessadas por fluxos vitais e vinculadas às dinâmicas da vida e da natureza que, assim como a mente humana, também "vazam", como também argumentado ( $\mathrm{e}$, por consequência, alguns desses elementos parecem fugir dos olhos de um pesquisador-cartógrafo). São, portanto, objetos que ganham vida, tornam-se coisas "abertas", tornam-se/formam-se brinquedos/aprendizagens/sensações, a partir do olhar das crianças e dos bebês que, por sua vez, foram agenciados/emaranhados/seduzidos por elas (agenciaram-se, emaranharam-se, seduziram-se), sem que os adultos sequer suspeitem ou possam antecipar essas forças. No entanto, estão imersos nelas.

\section{Joaquim $E$ a experiência com o som}

Em dois desses encontros com o bebê e sua mãe, tive a oportunidade de acompanhar alguns acontecimentos gerados pela relação de Joaquim com materiais sonoros e com o som. $\mathrm{O}$ primeiro evento foi quando a mãe ofereceu a ele uma boneca que emitia som (Imagem 3 - boneca circulada), enquanto estava com o aparelho auditivo.

Naquela visita, chamou-me a atenção o fato de que, quando Joaquim alcançou a boneca, quis continuar com ela, manipulando e a colocando na boca. No entanto, quando a mãe ativou o som desse material, o bebê ficou parado, atento (aparentemente assustado ou em estranhamento), muito sério (parou de sorrir, imediatamente), chegando a fazer uma expressão de choro. De fato, o som chegava a ser um pouco estridente, sob minha perspectiva ouvinte. Compreendi que o som atravessou fortemente a relação de Joaquim com o material/ brinquedo. Causou-lhe uma experiência singular. O som "vazou" para Joaquim e modulou o curso do seu trajeto e de suas ações e afetos no sofá da sala, sob nossos olhares. Alterou também a percepção da mãe que, então, decidiu desligar o aparelho sonoro do material/brinquedo. A partir daí, Joaquim seguiu manipulando e re-agindo a outros materiais.

\footnotetext{
${ }^{26}$ Por isso, talvez, esses acontecimentos - a partir daquilo que acaba chamando a atenção das crianças e dos bebês e ganhando protagonismo - que rompem o esperado até pelos adultos - sejam compreendidos, via de regra, como "lúdicos" - em si - e não a partir de suas forças de agenciamento e de seus fluxos materiais (forças "de atração" para além do próprio objeto)?
} 


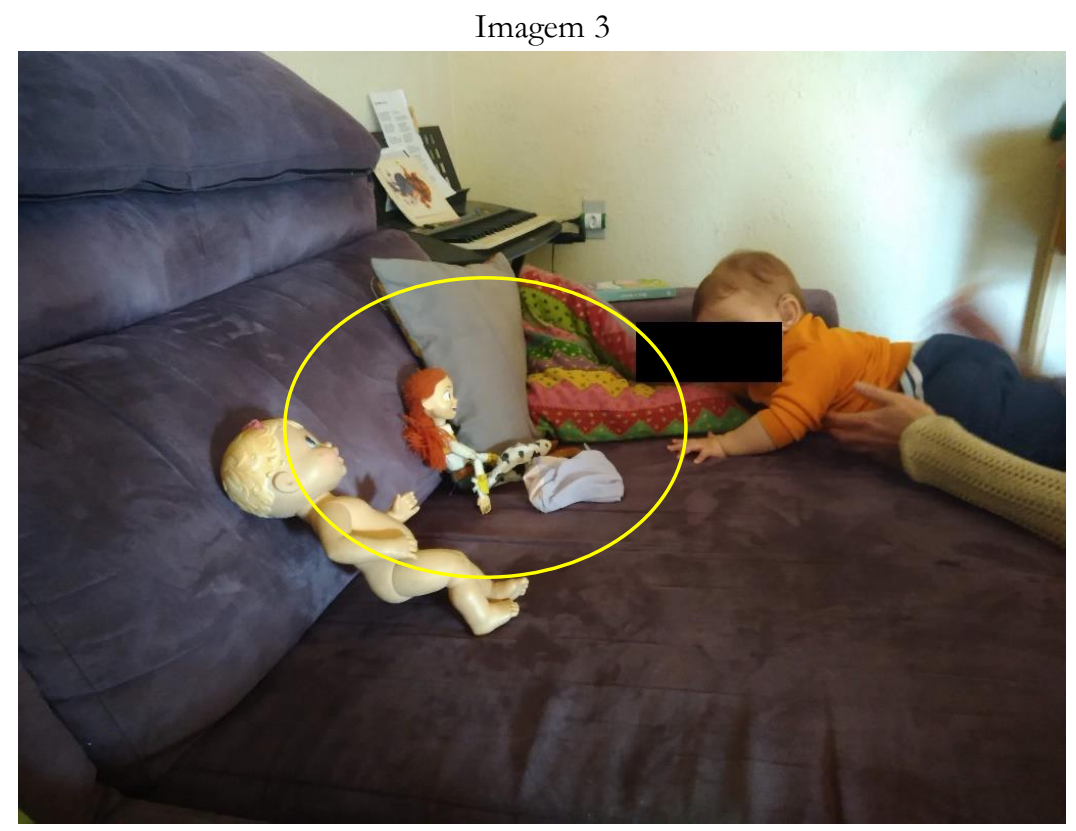

Fonte: acervo da autora

Signifiquei, naquele momento, essa experiência do bebê surdo como muito simbólica, por variados motivos. Uma primeira dimensão dessa reflexão foi sobre o fato de que o bebê mudava o curso de suas ações em função dessa relação com os materiais sonoros e também em função de outro material que era justamente o aparelho auditivo, colocado/escolhido pelos $\operatorname{adultos}^{27}$. Movimentos aberrantes sobressaíram-se ali, portanto, em minha perspectiva (e me desafiavam a cartografar, de modo que esses aspectos pudessem ser revelados para além de uma "rede com pontos"): o que acontecia com a percepção de Joaquim na presença ou não de emissões sonoras E com e sem o aparelho auditivo. Nas palavras de Ingold, seria buscar o traçado de uma "rede de vida" ou malha de linhas entrelaçadas (2015: 111).

Do contrário (sem a materialidade do aparelho), a experiência poderia ter sido outra, ou em outra intensidade. O que procuro destacar nesse primeiro aspecto é a modulação também subjetiva/cognitiva/afetiva do bebê, de sua compreensão/ aprendizagem/ sensibilidade sobre o mundo, as coisas, diante de muitos atravessamentos de forças e fluxos. Esse bebê surdo - naquele momento com aparelho - mas que num futuro que se aproximava já seria implantado - deveria ser pensado (como tantos outros casos), destacadamente, sob a perspectiva da trans-humanidade, por exemplo? Certamente, suas experiências cotidianas, em função desses materiais (de "apoio à audição"), serão atravessadas e modificadas. Não se trata apenas de "passar a ouvir". Essa experiência com o som (e, portanto, com o silêncio), nas condições em questão (de "vazamento"),

\footnotetext{
${ }^{27}$ Refiro-me aqui ao dispositivo médico como desencadeador de práticas e condutas que podemos conceber como afeitas ao biopoder, na acepção foucaultiana. Ao dispositivo médico que captura as famílias e as crianças nessa condição. Tais famílias passam a conceber, evidentemente, que é necessário, ou até mesmo fundamental/vital, o uso de aparelhos auditivos ou do implante coclear para a atuação cotidiana do bebê ou da criança.
} 
pode gerar impactos/fluxos/forças que desconhecemos, na condição de ouvintes e também de adultos $^{28}$.

Uma outra dimensão dessa reflexão se referiu, em consequência do exposto, ao que nós ouvintes e surdos concebemos como sendo "o som" e como concebemos "o ouvir o som". O que é barulho nessa "paisagem sonora"? O que é des-agradável (de se ouvir ou de não se ouvir) nesse âmbito? O que esses atravessamentos nos geram e como re-agimos a eles (de modo aparente ou não)?

Uma última questão que mereceria destaque (embora haja tantas outras em perspectiva) é em relação a como temos separado, talvez enclausurado, os tais "sentidos humanos" em categorias em si, portanto, não concebendo essa capacidade humana de sentir o mundo de modo híbrido/ atravessado e plural.

Ingold (2015) questiona "o que seria o som" e a nomeada "paisagem sonora" (conceito que o autor problematiza e discorda), enfatizando a natureza amalgamada de se sentir o mundo:

[...] o ambiente que experimentamos, conhecemos e no qual nos movimentamos não está fatiado ao longo das linhas sensoriais através das quais entramos nele. $O$ mundo que percebemos é o mesmo mundo, seja qual for o caminho que tomemos, e, ao percebê-lo, cada um de nós age como um centro indiviso de movimento e consciência. Por essa razão, deploro a moda de se multiplicarem paisagens de todo tipo possível. (Ingold, 2015: 206)

Enfim, em duas outras situações, Joaquim voltou a se relacionar com o som, de modo que eu assim presenciasse e compreendesse (esse som que as pessoas ouvintes parecem conceber e atentar). Uma delas foi num dia que cheguei em sua casa e ele havia acabado de acordar. Estava ainda bastante sonolento e a mãe o deixou sem aparelho auditivo. Ele estava muito tranquilo, começando a interagir comigo, com ela e com as coisas. Em seguida, a mãe resolveu colocar o aparelho nele e tentar me mostrar a "diferença" que percebia em suas ações, conforme me disse. Joaquim já estava sentado no sofá. Assim que o aparelho foi colocado, de fato, houve uma atenção para elementos com os quais talvez ele não fosse agenciado antes. Passava a perceber algo em torno dele e observava ou agia, aparentemente, em função dessas coisas que notava (na maior parte das vezes, sons mais intensos emitidos na sala: dos cachorros, da conversa entre mim e a mãe, algum objeto que caía, etc.).

No entanto, na sequência desse curto período em que passou a usar o aparelho, houve um ruído tão intenso (agudíssimo, tal como efeito microfônico) que nós chegamos a ouvir e ele ficou com seu corpo "congelado", parecendo buscar entender o que estava acontecendo no ambiente, mas talvez sentindo medo a partir daí. Chorou intensamente, então, e logo o aparelho parou de fazer aquele efeito. Esse incômodo havia durado muito pouco tempo, mas causou uma mudança visível no bebê. Enquanto a mãe tentava acalmá-lo também, continuou a explorar o que havia no sofá, parando de chorar.

\footnotetext{
${ }^{28}$ É importante considerar tais dimensões (não apenas do som, mas da visualidade, odores, paladares, etc.) na discussão sobre os emaranhados aqui mencionados, na relação com quaisquer sujeitos, como nos propõe também Ingold (2015). Educação em Revista|Belo Horizonte|v.37|e235031|2021
} 
Um outro acontecimento afeito a essa relação de Joaquim com o som foi gravado espontaneamente pela mãe e a mim enviado como arquivo de vídeo, abaixo disponível através do link:

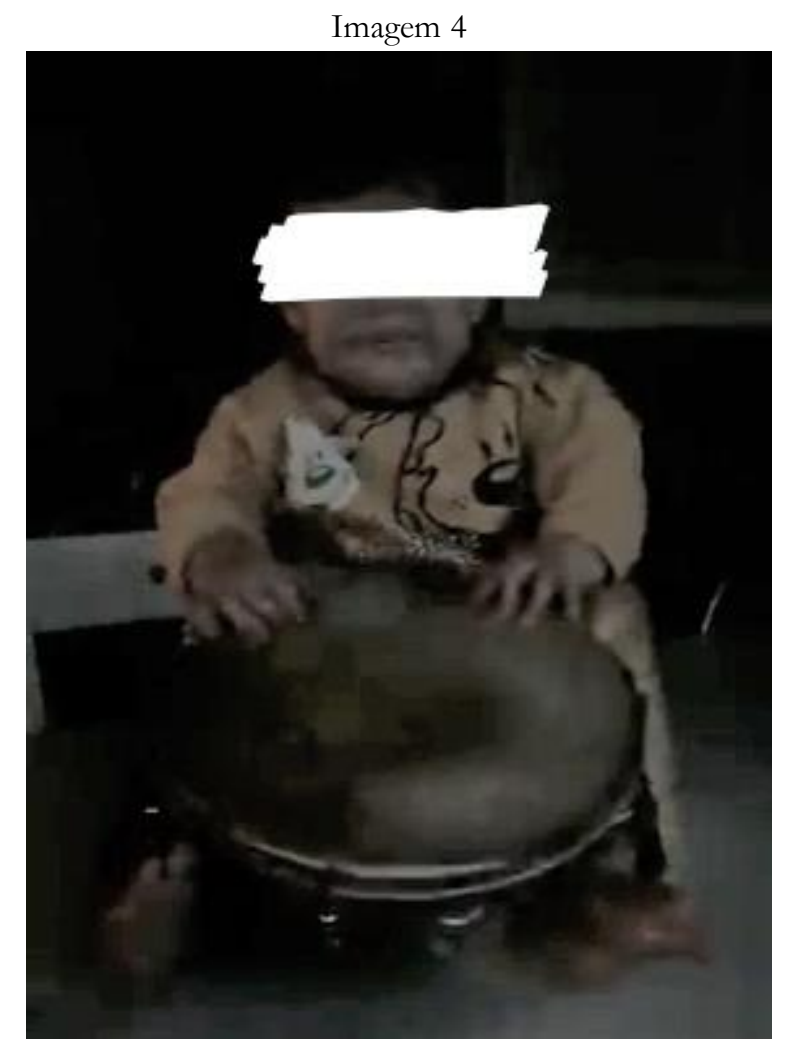

Fonte: vídeo disponível em https://www.youtube.com/watch?v=rbSw6Vo4aw0

Nesse breve registro, no que diz respeito à relação de Joaquim (sem o aparelho auditivo) com o material-pandeiro-brinquedo e o som, observamos que seu corpo está quase que completamente envolvido na experiência, ao ponto de explorar seus pés de uma forma (talvez) semelhante à que manipula o pandeiro (com o pandeiro no colo, bate e escorrega as mãos pela superfície do instrumento, em alguns momentos; sacode os pés e as pernas também para movimentá-lo). Parece tentar extrair daí (dos pés e também das mãos) alguma sensação que não se limita ao material, tratando-se de algo que é expandido/vazado em seu corpo (algo também parecido com o conceito de corpo sem órgãos, anteriormente comentado). Faria seu pé algo semelhante ao que faz o pandeiro (o som ou a vibração que sente)? As mãos que batem, rapidamente, e também se estendem, mais lentamente, pelo couro do pandeiro buscam essa sensação? Joaquim busca ouvir/sentir seu pé da forma como pode ouvir/sentir o pandeiro? O que o pandeiro, objetiva/subjetiva e afetivamente provoca/agencia em Joaquim, para além de uma representação que possamos evocar sobre o brincar? O que ele busca apreender dessa experiência? O que apreende nesse emaranhado? O que podemos compreender, quais linhas de força podem ser traçadas - em termos de agência - sobre essas inter-ações corpo-pandeiro-som (amálgama/emaranhado/malha/plano de imanência), na medida em que o pandeiro (visualidade material) parece tão protagonista quanto Joaquim (seu pé, pernas, colo, mãos) e as vibrações/sons? 
Agências compartilhadas e expandidas. Nesse cenário, Ingold (2015) poderia contribuir na articulação de possíveis reflexões, quando afirma: "devemos, mais uma vez, levar os materiais mais a sério, pois é a partir deles que tudo é feito" (p. 67).

\section{CARTOGRAFIA DE LINHAS E FLUXOS (TAMBÉM MATERIAIS) NOS PROCESSOS DE SUBJETIVAÇÃO DOS BEBÊS: CONTRIBUIÇÕES DO PÓS-HUMANISMO E DE JOAQUIM PARA O CAMPO PEDAGÓGICO}

Diante do que aqui se apresentou e discutiu, parece fundamental retomarmos a proposição de Braidotti: o nosso desafio de mudança é que possamos pensar sobre e compor um novo "nós", como "as pessoas desaparecidas" (Braidotti, 2019: 128), para compreendermos melhor o mundo, as relações, as escolhas socialmente engendradas, os espaços (e as representações) que têm as crianças, os bebês, a natureza e os materiais nesses contextos, as dis-res-sonâncias surgidas, dentre outros aspectos. Dessa percepção e sensibilidade(s) podem surgir novas compreensões éticas sobre quem somos - assim como sobre as crianças, os bebês e ao que nos invocam- e, portanto, sobre nossas relações e impactos no mundo. Braidotti (2019: 144) menciona, fundamentalmente, com essa nova epistemologia, a necessidade de um objetivo ético do plano afirmativo de composição de subjetividades transversais (termos rizomáticos que envolvem territórios, geologias, ecologias e tecnologias de sobrevivência).

Ainda seria fundamental apontar, a partir da discussão aqui tecida sobre um bebê surdo nesses emaranhados, que mais uma vez é preciso subverter a ideia de deficiência e dos estudos da deficiência (Disability Studies) para o que Goodley (et.al, 2014, 2018, citado por Braidotti, 2019: 139) chama(m) de DisHuman Studies (Estudos DesHumanos), buscando resistir e romper com as narrativas "auto-engrandecedoras" sobre o ser humano como algo patrocinado pelo humanismo eurocêntrico que focaliza os aspectos neoliberais e "das capacidades", da imagem ideal do cidadão como unidade de produção funcional (o que significa ser humano, portanto, na concepção humanista clássica e tradicional), como também aponta a autora. Todos esses aspectos, evidentemente, contribuem para que projetemos uma compreensão do que seria uma Pedagogia Pós-bumana também (Braidotti, 2019), uma Pedagogia intra-ativa ${ }^{29}$ (Lenz Taguchi, 2010, citado por Moss, 2019) ou uma Pedagogia das relações e escuta (Dahlberg \&Moss, 2020; Rinaldi, 2020), para que sejam exploradas novas perspectivas de ensino, aprendizado e pesquisa, em destaque também neste estudo.

Cumpre ressaltar que tais pedagogias - e mesmo qualquer outra influenciada por perspectivas pós-humanas - descentralizam os seres humanos e isso também se refere às crianças/ bebês, como aqui foi argumentado. Isso significa conceber, mais uma vez, a ênfase no emaranhamento, havendo contestação da ideia do foco na criança, tão comuns na educação infantil de hoje, conforme também destacou Moss (2019).

Nesse giro conceitual, a criança e o bebê passam a ser compreendidos a partir de novos referenciais híbridos e como seres "vazados" pelo/para o mundo. Nas palavras de Murris, "a criança pós-humana é, portanto, 'um emaranhado, constituído por conceitos e forças materiais, onde as máquinas sociais, políticas, biológicas e suas máquinas de medir, controlar e observar estão entrelaçadas - todos os elementos intra-atuam" "(Murris, comunicação pessoal, citado por Moss, 2019: 150).

\footnotetext{
${ }^{29}$ Segundo Moss (idem), tal pedagogia explora as implicações para a educação sobre o envolvimento do humano e do não-humano, do discursivo e do material.
} 
Faz-se fundamental considerar - também no campo pedagógico - que se trata de uma espécie de nascimento contínuo, de um modo de ser (também dos bebês) que está vivo e aberto ao mundo não pronto. Trata-se de um processo de (re)surgimento com esse mundo também em formação, através das linhas de seus relacionamentos, como também Ingold (2015) nos ajuda a vislumbrar. Considero, assim, que uma mudança paradigmática entraria em curso no campo da educação que lançaria, neste caso, um outro modo de compreensão e percepção dos processos em jogo, durante o desenvolvimento das crianças e bebês, por exemplo. Essencialmente, uma pedagogia do fora ou pedagogia trans-pós-humana, de redimensionamento/ desterritorialização profunda de saberes. Em outras palavras, seria uma pedagogia da escuta das coisas.

A esse respeito, julgo bastante importante avançarmos nas pesquisas na área, também no Brasil, destacadamente no campo educacional. Nos últimos anos, no geral, temos acompanhado um expressivo aumento no interesse pelas questões entre materialidade e infância, nos Estudos da Infância ${ }^{30}$, mas podemos observar que as concepções de agência ficam, via de regra, em torno do antropocentrismo ${ }^{31}$. Vale lembrar que, ao mesmo tempo, também no Brasil, uma expressão dessa preocupação epistemológica não antropocêntrica tem ocorrido, da forma como analiso, através de abordagens em torno de uma pedagogia decolonial. Contudo, por exemplo, no campo da educação, para além da decolonialidade, não foram localizados - até o momento - estudos sobre o póshumanismo ou pós-humano como categorias específicas teórico-metodológicas ${ }^{32}$.

O fato é que, em síntese, o papel dos fluxos materiais, por certo, surge destacado nessa pedagogia das relações que se propõe, de fato, "da escuta" não apenas dos humanos (como apontado aqui, a partir das considerações de Moss, 2019; Dahlberg \&Moss, 2020; Ingold, 2015). Significa considerar, de modo mais abrangente, uma decorrência dessa sensibilidade outra que traria a concepção de mundo (das próprias relações) que não pode ser simplesmente "ensinado" como algo pronto ou dado, porque é compreendido em co-construção. É possível colocar no horizonte, com esse gesto mais panorâmico sobre tal pedagogia trans-pós-bumana, um outro modo de vida num planeta há tanto ameaçado por concepções e práticas educativas antropocêntricas (e, como bem sabemos, definidora de agências também antropocentradas: jamais em relação com esse mundo, de fato, em pé de igualdade, ou em "sua escuta"), como aqui discutido de início. Uma pedagogia também aberta e porosa, assim, ao mundo re-agente, aos sentidos e impactos das relações (micro e macropolíticas), às crianças e bebês e mais afeita às perguntas nesses contextos (pois está também em movimento: atravessada e em travessia). Nessa direção, seu desafio também seria se orientar

\footnotetext{
30 Informação obtida a partir de anotações pessoais da palestra do prof. José Manuel Sarmento, UMinho, que apresentou uma espécie de "estado da arte" dos Estudos da Infância no 6․ Grupeci, novembro de 2018, em Belém: https://anped.org.br/content/6-o-grupeci. Acesso em 27.02.2020.

31 Prof. Sarmento apontou, no mesmo evento, o VIII Conference on Childhood Studies, ocorrido em 2018, na Finlândia, como um dos lócus recentes de concentração da discussão sobre materialidade e as infâncias (https://congress.cc.jyu.fi/childhood2018/schedule/sessionl/sessionl0t0.html). A partir de um breve mapeamento no programa e nos resumos apresentados, observei que o tema "pós-humanismo" surge relacionado à Educação Ambiental e sustentabilidade (houve duas sessões no evento). Quanto à materialidade (e agência), surgiram trabalhos relacionados à temática da leitura, cuidado, cotidiano, práticas institucionais, espaço, por exemplo.

32 Até 31.8.2020 não foram encontradas referências na base Scielo (idem), através dos marcadores "pós-humano" ou pós-humanidade" e "educação". Em pesquisa realizada no site Ibict (idem), com os marcadores "pós-humano" ou "pós-humanismo", alguns trabalhos estão disponíveis e foram produzidos nos últimos anos, principalmente nas seguintes áreas: Comunicação e Semiótica, Ciência da Informação, Artes, Artes Visuais, Ciências Sociais, Computação Aplicada, Direito, Letras e Filosofia, mas não no campo da Educação.
} 
por outras bússolas que não as mesmas das epistemologias da branquitude, euro-humanoreferenciadas, tal como proposto pela pedagogia decolonial.

Também a partir de Ingold (2015: 112), nesse mundo em devir, podemos projetar essa pedagogia que reinstaure o espanto e o imprevisível, como se estivéssemos "sentindo seu pulso, maravilhando-nos com sua beleza e nos perguntando como um mundo assim é possível", algo lamentavelmente banido da ciência oficial. Nesse amplo projeto político-pedagógico, condutores muito potentes seriam os bebês e as pistas que possibilitam, através de seus processos de agenciamento/ acoplamento, por certo. Afinal, já nos tornamos adultos/profissionais subjetivados através daqueles modos antropocêntricos e competitivos/capacitistas do mundo do trabalho/social, como regra, isto é, frequentemente assujeitados pelos mecanismos de funcionamento do Capitalismo Mundial Integrado, no dizer de Guattari (2012), aqui mencionado. Sobre tal aspecto, o autor ainda destaca:

[...] a subjetividade capitalística se esforça por gerar o mundo da infância, do amor, da arte, bem como tudo o que é da ordem da angústia, da loucura, da dor, da morte, do sentimento de estar perdido no cosmos...É a partir dos dados existenciais mais pessoais - deveríamos dizer mesmo infrapessoais - que o CMI [Capitalismo Mundial Integrado] constitui seus agregados subjetivos maciços, agarrados à raça, à nação, ao corpo profissional, à competição esportiva, à virilidade dominadora, à star da mídia [...] (Guattari, 2012: 34, grifo meu).

Diante desse contexto, como foi vislumbrado no início do estudo, foram percorridas linhas e fluxos, nesse território com Joaquim (penso que seja uma espécie de nosso principal guia), que sugerem a força das coisas/dos materiais em seu processo de subjetivação (as coisas com as quais interagiu: seu aparelho auditivo, por exemplo, e tantas outras). Do mesmo modo, nesse relevo formado por desejos, encontros, agenciamentos e emaranhados, observamos movimentos de repetição sobre a condição da surdez, isto é, a surdez não como potência - do ver/sentir, por exemplo - mas como falta (falta a ser compensada pelo aparelho ou pelo implante coclear). Movimentos que surgem com intensidade nessa breve experiência de vida, em seu processo de constituição como um ser/ como um ser surdo, em sua família e em tantas outras relações (como as escolas, num futuro próximo), já fortemente forjadas pelo dispositivo médico-nosológico.

Por outro lado, pudemos observar que Joaquim revela linhas de voo sobre modos de conhecer o mundo (onde se incluem os sons/as vibrações e tantas outras sensações) e busca sentidos/trajetos/aconteceres que vão muito além de sua condição auditiva, como um nômade e aventureiro (onde há sensibilidades/percepções outras). Joaquim dispõe todo seu corpo/mente na criação de emaranhados/malhas sensoriais nessa empreitada, tal como "qualquer bebê", como tarefa para preencher um plano de imanência, "toda uma vida", como nos lembrou Deleuze (2002), colocando-se em agência expandida com o que/quem encontra - e também se projeta, re-age - nesse caminho.

Concebo os emaranhados de Joaquim, também a partir de um encontro particular que gostaria, finalmente, de compartilhar. Há cerca de uns dois anos atrás, em diálogo com uma liderança indígena Kariri-Xocó, perguntei a respeito do cotidiano das pessoas surdas no seu povo. Ele me disse que esses Kariri-Xocó compreendem que as pessoas "chamadas surdas" possuem uma maior sensibilidade com o mundo espiritual, em suas palavras; um "dom". Como me 
exemplificou esse líder, pessoas surdas seriam uma espécie de "celular" que recebem os sinais "externos", do "alto".

Também com tal perspectiva, busco, por fim, enfatizar que compreender o voo de Joaquim, seus gestos iniciais numa vida por vir, através de apenas um fluxo/ linha/ modo de agenciamento: a ideia de "ouvir/ não ouvir" - algo tão naturalizado em nossa sociedade - é deixar todo um mundo de possibilidades pós-trans-humanas desconhecido e inexplorado (para ele e para os outros). Mais que isso, em função de agenciamentos da tradição moderna, colonial e ocidental, tal pensamento reduz potenciais desconhecidos em deficiência, preparando e reservando, assim, outros mapas, principalmente para alguns bebês e crianças (onde as diferenças se desdobram em mera falta), seus processos de subjetivação e condições de existência.

\section{REFERÊNCIAS}

Acosta, A. (2016). O bem viver: uma oportunidade para imaginar outros mundos. São Paulo: Autonomia Literária. Elefante.

Braidotti, R. (2013).The Posthuman. Cambridge: Polity Press.

Braidotti, R. (2019). Posthuman Knowledge. Cambridge: Polity Press.

Brougère, G. (2010). Brinquedo e Cultura. São Paulo: Cortez.

Bujes, M. I. E. (2008). Artes de governar a infância: linguagem e naturalização da criança na abordagem de educação infantil da Reggio Emília. Educação em Revista, (48), 101-123.

Dahlberg, D. \& Moss, P. (2020). Introdução: Nossa Reggio Emilia. In: Rinaldi, C. (2020). Diálogos com Reggio Emilia: escutar, investigar e aprender; tradução de Vania Cury. - 10ª. ed. Rio de Janeiro/ São Paulo: Paz e Terra. Deleuze, G. (2013). Conversaçoes. 3ª. ed. São Paulo: Editora 34. (Coleção TRANS).

Deleuze, G. \& Guattari, F. (1995). Mil Platôs: capitalismo e esquizofrenia. Vol.I. São Paulo: Ed.34. (Coleção TRANS)

Deleuze, G. \& Guattari, F. (1996). Mil Platôs: capitalismo e esquizofrenia. Vol.III. São Paulo: Ed.34. (Coleção TRANS)

Deleuze, G. (2002). A imanência: uma vida. Educação \& Realidade. 27 (2):10-18, jul./dez. Disponível em: https://seer.ufrgs.br/educacaoerealidade/article/view/31079/19291.

Derrida, J. (2012). Jacques. Uma certa possibilidade impossível de dizer o acontecimento. [1997] . Revista Cerrados, v. 21, n. 33, 3 set.

Guattari, F. (2012). As três ecologias. 21ª . edição. Campinas: Papirus, 2012.

Haraway, D. (2004). Otherworldly conversations: terran topics; local terms. In: The Haraway Reader. London: Routledge.

Ingold, T. (2012). Trazendo as coisas de volta à vida: emaranhados criativos num mundo de materiais. Horizontes Antropológicos, Porto Alegre, ano 18, n. 37: 25-44, jan./jun. 
Ingold, T. (2015). Estar vivo: ensaios sobre movimento, conhecimento e descrição. Petrópolis, RJ: Vozes. (Col. Antropologia).

Lapoujade, D. (2015). Deleuz̧e, os movimentos aberrantes. São Paulo: n-1 Edições.

Leclercq, S. (2002). Deleuze e os bebês. Educação \& Realidade. 27 (2):19-29, jul./dez. Disponível em: https://seer.ufrgs.br/educacaoerealidade/article/view/25913 .

Lenz Taguchi, H. (2010). Rethinking pedagogical practices in early childhood education: A multidimensional approach to learning and inclusion. In: N. Yelland (ed) Contemporary Perspectives on Early Childhood Education. Maidenhead: Open University Press.

Mignolo, W. (2017). Desafios coloniais hoje. Epistemologias do Sul, Foz do Iguaçu/ PR, 1 (1), p. 1232. Disponível em:

https://revistas.unila.edu.br/epistemologiasdosul/article/download/772/645

Moss, P. (2019). Alternative Narratives in Early Childhood: An Introduction for Students e Practitioners. New York: Routledge. (Contesting Early Childhood).

Murris, K. (2016). The Posthuman Child: Educational Transformation Through Philosophy With Picturebooks. London: Routledge.

Oliveira, L. F.; Candau, V. M. F. (2010). Pedagogia decolonial e educação antirracista e intercultural no Brasil. Educ. rev., Belo Horizonte, v. 26, n. 1, p. 15-40, Apr. Disponível em: http://www.scielo.br/scielo.php?script=sci_arttext\&pid=S010246982010000100002\&lng=en $\&$ nrm $=$ iso

Oliveira, T.M. \& Paraíso, M.A. (2012). Mapas, dança, desenhos: a cartografia como método de pesquisa em educação. Pro-Posições. v. 23, n. 3 (69): 159-178, set./dez. 2012.

Pavez Soto, I., Sepúlveda Kattan, N. (2019): Concepto de agencia en los estudios de infancia. Una revisión teórica, Sociedad e Infancias, 3, 193-210

Placer, F. (2001). O outro hoje: uma ausência permanentemente presente. In: Larrosa, J.; Skliar, C. Habitantes de Babel: políticas e poéticas da diferença.

Quijano, A (2005). Colonialidade do poder, Eurocentrismo e América Latina. In Quijano, A. A colonialidade do saber: eurocentrismo e ciências sociais. Perspectivas Latino-Americanas. CLACSO. Disponível em: Disponível em: http://biblioteca.clacso.edu.ar/clacso/sur$\underline{\text { sur/20100624103322/12 Quijano.pdf }}$

Rinaldi, C. (2020). Diálogos com Reggio Emilia: escutar, investigar e aprender; tradução de Vania Cury. $-10^{a}$. ed. Rio de Janeiro/ São Paulo: Paz e Terra.

Rolnik, S. (2018). Esferas da insurreição: notas para uma vida não cafetinada. São Paulo: n-1 Edições.

Skliar, C.B. (1997). Uma perspectiva sócio-histórica sobre a psicologia e a educação dos surdos. In Skliar, C. (Org.). Educação \& exclusão: abordagens sócio-antropológicas em educação especial, pp. 105-153. Porto Alegre: Mediação.

Santos, B.S. \& Meneses, M.P. (2010) (org). Epistemologias do Sul. São Paulo: Cortez, 2010. 
Santos, B.S. (2019). O fim do império cognitivo: A afirmação das epistemologias do Sul. 1ª . Ed. Belo Horizonte: Autêntica Editora.

Santos, B.S. \& Martins, B.S. (2019) (orgs). O pluriverso dos direitos bumanos: a diversidade das lutas pela dignidade. $1^{\text {a }}$. Ed. Belo Horizonte: Autêntica Editora. (Epistemologias do Sul; 2)

Sarmento, M.J. (2005). Gerações e alteridade: interrogações a partir da sociologia da infância. Educação e Sociedade, Campinas, v. 26, n. 91, ago.

Taylor, A. (2013). Reconfiguring the Natures of Childhood. London: Routledge.

Tebet, G. (2017). Desemaranhar as linhas da infância: elementos para uma cartografia. In: Abramowicz, A.; Tebet, G. (orgs). Infância e pós-estruturalismo. São Paulo: Porto de Idéias.

Walsh, C. (2009). Interculturalidade Crítica e Pedagogia Decolonial. In: Candau, V. M. (Ed.). Educação Intercultural na América Latina: entre concepções, tensões e propostas. Rio de Janeiro: 7letras, p. 12-42.

Submetido: $11 / 03 / 2020$

Aprovado: 10/09/2020 